\title{
BOAT PRESSURE WASHING WASTEWATER TREATMENT WITH CALCIUM OXIDE AND/OR FERRIC CHLORIDE
}

\author{
Višnja OREŠČCANIN ${ }^{1}$, Robert KOLLAR ${ }^{1}$, Karlo NAĐ ${ }^{1}$, Ivanka LOVRENČIĆ MIKELIĆ ${ }^{2}$ \\ and Nenad MIKULIĆ ${ }^{3}$
}

\begin{abstract}
Advanced Energy Ltd ${ }^{1}$, Laboratory for Radioecology, Institute R. Boskovic ${ }^{2}$, Ministry for Environmental Protection and Physical Planning and Construction ${ }^{3}$, Zagreb, Croatia
\end{abstract}

Received in January 2012

CrossChecked in January 2012

Accepted in February 2012

\begin{abstract}
The aim of this study was to investigate the efficiency of (1) chemical precipitation by calcium oxide, (2) coagulation/flocculation by ferric chloride (FC), and (3) the combination these two methods in reducing the toxicity of wastewater generated by boat pressure washing. All three methods gave satisfactory results in the removal of colour, turbidity, $\mathrm{Cr}, \mathrm{Fe}, \mathrm{Cu}, \mathrm{Zn}$, and $\mathrm{Pb}$. The concentrations of heavy metals were lowered below national limits with $1 \mathrm{~g}$ of $\mathrm{CaO}, 2.54 \mathrm{mg}$ of $\mathrm{Fe}^{3+}$ in the form of $\mathrm{FeCl}_{3} \times 6 \mathrm{H}_{2} \mathrm{O}$, and the combination of $0.25 \mathrm{~g}$ of $\mathrm{CaO}$ and $5.08 \mathrm{mg}$ of $\mathrm{Fe}^{3+}$ per $50 \mathrm{~mL}$ of wastewater. Both $\mathrm{CaO}(1.50 \mathrm{~g}$ per $50 \mathrm{~mL}$ of wastewater) and $\mathrm{FC}$ proved efficient, but their combination yielded a significantly better performance: $99.41 \%$, $100.00 \%, 97.87 \%, 99.09 \%, 99.90 \%, 99.46 \%$ and $98.33 \%$ for colour, turbidity, $\mathrm{Cr}, \mathrm{Fe}, \mathrm{Cu}, \mathrm{Zn}$, and $\mathrm{Pb}$ respectively. For colour, $\mathrm{Cr}, \mathrm{Cu}, \mathrm{Zn}$, and $\mathrm{Pb}$ removal efficiencies increased in the following order: $\mathrm{FC}<\mathrm{CaO}<\mathrm{CaO}+\mathrm{FC}$, while this order for turbidity and $\mathrm{Fe}$ was as follows: $\mathrm{CaO}<\mathrm{FC}<\mathrm{CaO}+\mathrm{FC}$. As expected, all three methods increased the concentration of total dissolved solids in the final effluent. Our results suggest that the combined treatment of marina wastewaters with calcium oxide followed by ferric chloride is efficient, cost-effective, and user-friendly.
\end{abstract}

KEY WORDS: antifouling paints, CaO, chromium, colour, copper, lead, heavy metals, turbidity, zinc

The major source of heavy metals in the sediments around shipyards and marinas are the antifouling paints (1) that have been extensively used for boat protection for over the last 100 years (2). Antifouling paints contain strong agents that kill algae and other organisms and prevent them from attaching to the hull (2). Efficient protection usually requires that the hull be treated once a year (1). Old paint is removed by pressure washing that generates $100 \mathrm{~L}$ to $150 \mathrm{~L}$ of wastewater per boat. This amount of wastewater contains about four kilograms of paint distributed over particles of different size (3). The major biocide present in all paints is copper $(\mathrm{Cu})$. Other metals like zinc $(\mathrm{Zn})$, chromium $(\mathrm{Cr})$, titanium $(\mathrm{Ti})$, and lead $(\mathrm{Pb})$ can also be present, but their concentration varies with the brand and the type of paint(1). A number of studies (reviewed in ref. 1) have determined their genotoxic effects on marine environment, including extinction of local species.

There are over a hundred marinas along the Croatian Adriatic coast and most still release boat pressure washing wastewater directly into the sea.

Our group has been testing several physicochemical methods of wastewater treatment with red mud as coagulant, first in the laboratory $(4,5)$ and then full-scale (1). The average removal efficiency of the 
full-scale treatment was $99.6 \%$ for $\mathrm{Pb}$ and $\mathrm{Cu}$ and $99.9 \%$ for Zn. In a pilot-scale trial, Walker et al. (2) managed to remove over $98 \%$ of chemical oxygen demand (COD) from shipyard wastewaters using dolomite and dolomitic sorbents. Ottosen et al. (3) efficiently lowered $\mathrm{Cu}, \mathrm{Zn}$, and $\mathrm{Sn}$ levels in dockyard wastewaters to below regulatory limits using the coagulation/flocculation method with ferric chloride.

Coagulation/flocculation with alum and ferric sulphate was also efficient (99.8\%) in removing tributyltin from shipyard wastewaters in a laboratory and a full-scale system (6). In another study (7), organotin species was successfully removed from shipyard wastewaters by electrochemical oxidation using niobium coated with boron-doped diamond and titanium coated with iridium dioxide anodes (7). Vreysen et al. (8) combined adsorption with a bentonite-type adsorbent and coagulation/flocculation with activated carbon in powder and removed up to $98.7 \%$ of $\mathrm{Cu}$ and $99.4 \%$ of $\mathrm{Zn}$ from shipyard wastewaters.

The aim of this study was to develop and test a cost-effective and user-friendly laboratory-scale method combining precipitation with calcium oxide $(\mathrm{CaO})$ followed by neutralisation and coagulation/ flocculation with ferric chloride (FC) for the removal of inorganic/organic contaminants from wastewaters generated in marinas by boat pressure washing

\section{MATERIALS AND METHODS}

\section{Wastewater sampling and storage}

Wastewater generated from boat pressure washing was collected in the Marina Kaštela, Kaštel Gomilica, Croatia. The effluent was collected in a channel with fine grate at the end. To obtain representative samples, eight boats with different paint coatings (different colour and brand) were washed. One hundred litres of wastewater was sampled. Before purification, wastewater was homogenised as described in our previous research (9).

\section{Purification experiments}

All purification experiments were conducted at $22{ }^{\circ} \mathrm{C}$. The treatment with $\mathrm{CaO}$ was performed as follows; aliquots of wastewater $(50 \mathrm{~mL})$ were mixed with $0.25 \mathrm{~g}, 0.50 \mathrm{~g}, 1.00 \mathrm{~g}$, or $1.50 \mathrm{~g}$ of $\mathrm{CaO}$ (Lička tvornica vapna, Ličko Lešće, Croatia) (12). After adding $1.50 \mathrm{~g}$ of calcium oxide, we lowered the $\mathrm{pH}$ to 9 by adding $4 \mathrm{~mol} \mathrm{~L}^{-1}$ of hydrochloric acid (Kemika, Zagreb, Croatia). The suspension was mixed for 10 minutes on a magnetic stirrer (30 MAG 12, Labline Stock Centre, Mumbai, India; $200 \mathrm{rpm}$ ) and left to settle for 30 minutes. After floc sedimentation, clear water was decanted and analysed.

Treatment with ferric chloride (FC), $\mathrm{FeCl}_{3} \times 6 \mathrm{H}_{2} \mathrm{O}$ (Kemika, Zagreb, Croatia), was performed as follows; aliquots of wastewater $(50 \mathrm{~mL})$ were mixed with the $1.27 \mathrm{mg}, 2.54 \mathrm{mg}, 3.81 \mathrm{mg}$, or $5.08 \mathrm{mg}$ of $\mathrm{Fe}^{3+}$ added in the form of ferric chloride. Due to the drop in $\mathrm{pH}$ caused by $\mathrm{Fe}^{3+}$ hydrolysis, we had to adjust it to 8 by adding ammonium hydroxide (Kemika, Zagreb, Croatia). The suspension was mixed on a magnetic stirrer for 15 minutes and left to settle for 30 minutes.

For the combined treatment, we mixed wastewater aliquots $(50 \mathrm{~mL})$ with $0.25 \mathrm{~g}, 0.50 \mathrm{~g}, 1.00 \mathrm{~g}$, or $1.50 \mathrm{~g}$ of $\mathrm{CaO}$ on a magnetic stirrer without $\mathrm{pH}$ adjustment. After 10 minutes, we added $5.08 \mathrm{mg}$ of $\mathrm{Fe}^{3+}$ into each beaker and mixed on a magnetic stirrer for another 15 minutes, and let it settle for 30 minutes.

All experiments were done in triplicate. In all cases, the relative standard deviation (RSD) was less than $10 \%$.

\section{Sample preparation and analysis}

Untreated and treated wastewater was prepared for the analysis as follows: $5 \mathrm{~mL}$ of untreated effluent and $100 \mathrm{~mL}$ of purified effluent were adjusted to $\mathrm{pH} 3$ by adding hydrochloric acid (Kemika) or ammonium hydroxide (Kemika) preconcentrated (9) with ammonium-pyrolidinedithiocarbamate (APDC) (Merck, Schuchardt, Germany). Wastewater was filtered through Millipore micro filters and analysed using a MINIPAL4 X-ray spectrometer (PANalytical, Almelo, Nederland) (10-12). Colour and turbidity were determined using a HACH DR890 colorimeter (Hach Company, Loveland, Colorado, USA) $(9,12)$, while the $\mathrm{pH}$ and total dissolved solids (TDS) were determined using a PHT-027 water quality multiparameter monitor (Kelilong Electron, Fuan Fujian, China) $(9,12)$.

\section{Statistical analysis}

For statistical analysis we used the STATISTICA 7.0 software package. The level of significance in all tests was set to $\mathrm{P}<0.05$. Differences between treatment methods were tested using the analysis of variance and the Student-Newman-Keuls test. 


\section{RESULTS AND DISCUSSION}

\section{Chemical precipitation with $\mathrm{CaO}$}

Table 1 shows the results of the analysis of boat pressure washing wastewater. The baseline colour and turbidity and the respective concentrations of $\mathrm{Fe}, \mathrm{Cu}$, and $\mathrm{Zn}$ were 1.98, 16.23, and 5.58 times higher than the limit values for wastewaters to be discharged into a natural recipient.

Adding $0.25 \mathrm{~g}$ of $\mathrm{CaO}$ into $50 \mathrm{~mL}$ of wastewater resulted in $98.71 \%, 98.31 \%, 62.84 \%, 81.60 \%$, $90.60 \%, 95.42 \%$, and $59.36 \%$ removal of colour, turbidity, $\mathrm{Cr}, \mathrm{Fe}, \mathrm{Cu}, \mathrm{Zn}$, and $\mathrm{Pb}$, respectively (Figure 1). In spite of good removal efficiencies obtained for all seven parameters, the concentration of $\mathrm{Cu}$ in the final effluent was still 1.5 times higher than the maximum allowed level. The concentrations of all metals were lowered below the limit after adding $1 \mathrm{~g}$ of $\mathrm{CaO}$. A further increase to $1.50 \mathrm{~g}$ of $\mathrm{CaO}$ improved the final removal efficiency for colour and turbidity to $99.07 \%$ and $99.54 \%$, respectively. Removal efficiency of heavy metals increased linearly with the amount of $\mathrm{CaO}$. It increased the most for $\mathrm{Fe}$, followed by $\mathrm{Cu}$ and $\mathrm{Zn}$. The highest removal efficiencies for $\mathrm{Cr}, \mathrm{Fe}, \mathrm{Cu}, \mathrm{Zn}$, and $\mathrm{Pb}$ were $86.97 \%, 96.77 \%$, $97.81 \%, 98.76 \%$, and $84.10 \%$, respectively.

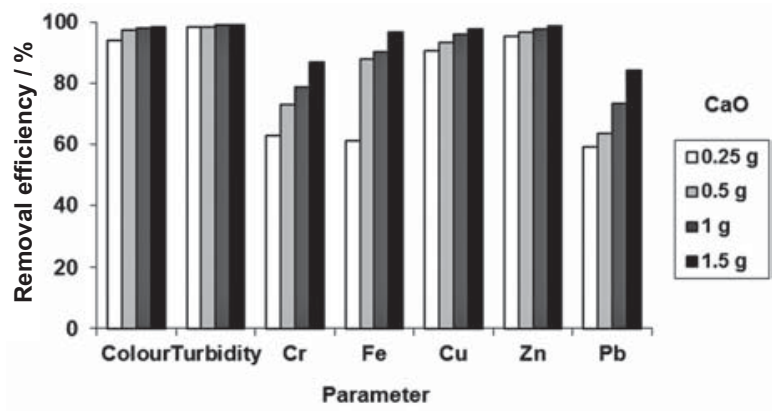

Figure $1 \mathrm{CaO}$ treatment removal efficiency. $\mathrm{CaO}$ amount expressed per $50 \mathrm{~mL}$ of wastewater.

\section{Coagulation/flocculation with ferric chloride}

With ferric chloride (Figure 2) we obtained better removal efficiencies for colour and turbidity than for heavy metals. Acceptable levels of heavy metals were obtained after adding $2.54 \mathrm{mg}$ of $\mathrm{Fe}^{3+}$. Removal efficiency increased linearly with further increases in the amount of coagulant for all seven parameters, and the final was as follows: $98.76 \%$ for colour, $99.85 \%$ for turbidity, $78.99 \%$ for $\mathrm{Cr}, 97.35 \%$ for $\mathrm{Fe}, 96.77 \%$ for $\mathrm{Cu}, 98.53 \%$ for $\mathrm{Zn}$, and $78.99 \%$ for $\mathrm{Pb}$. All measured parameters in the treated effluent below the maximum allowed level for wastewater suitable for discharge into the environment (Table 1).

Table 1 The values of the measured parameters, at baseline (before treatment) and after the treatment of $50 \mathrm{~mL}$ of wastewater with $1.50 \mathrm{~g}$ calcium oxide, $5.08 \mathrm{mg} \mathrm{Fe} e^{3+}$ in the form of $\mathrm{FeCl} \times 6 \mathrm{H}_{2} \mathrm{O}$ and their combination against maximum allowed levels that can be released into a natural recipient (13).

\begin{tabular}{|c|c|c|c|c|c|}
\hline \multirow{2}{*}{$\begin{array}{l}\text { Measured } \\
\text { parameter }\end{array}$} & \multirow{2}{*}{$\begin{array}{c}\text { Untreated } \\
\text { effluent }\end{array}$} & \multicolumn{3}{|c|}{ Treated effluent } & \multirow{2}{*}{$\begin{array}{c}\text { Maximum } \\
\text { allowed levels } \\
\text { (13) }\end{array}$} \\
\hline & & $\begin{array}{c}1.50 \mathrm{~g} \mathrm{CaO} \\
\text { per } 50 \mathrm{~mL} \text { of } \\
\text { wastewater }\end{array}$ & $\begin{array}{c}5.08 \mathrm{mg} \mathrm{Fe}{ }^{3+} \\
\text { per } 50 \mathrm{~mL} \mathrm{of} \\
\text { wastewater }\end{array}$ & $\begin{array}{c}(1.50 \mathrm{~g} \mathrm{CaO}+5.08 \mathrm{mg} \\
\left.\mathrm{Fe}^{3+}\right) \text { per } 50 \mathrm{~mL} \text { of } \\
\text { wastewater }\end{array}$ & \\
\hline Colour / PtCo & 8370 & 78 & 104 & 49 & $\begin{array}{c}\text { colourless on } \\
\text { visual inspection }\end{array}$ \\
\hline Turbidity / NTU & 1300 & 6 & 2 & 0 & $\begin{array}{c}\text { clear on visual } \\
\text { inspection }\end{array}$ \\
\hline $\mathrm{Cr} / \mathrm{mg} \mathrm{L}^{-1}$ & 0.890 & 0.116 & 0.187 & 0.019 & 0.5 \\
\hline $\mathrm{Fe} / \mathrm{mg} \mathrm{L}^{-1}$ & 3.968 & 0.128 & 0.105 & 0.036 & 2 \\
\hline $\mathrm{Cu} / \mathrm{mg} \mathrm{L}^{-1}$ & 8.118 & 0.178 & 0.262 & 0.008 & 0.5 \\
\hline $\mathrm{Zn} / \mathrm{mg} \mathrm{L}^{-1}$ & 11.162 & 0.138 & 0.164 & 0.060 & 2 \\
\hline $\mathrm{Pb} / \mathrm{mg} \mathrm{L}^{-1}$ & 0.790 & 0.124 & 0.187 & 0.013 & 0.5 \\
\hline $\mathrm{TDS} / \mathrm{mg} \mathrm{L}^{-1}$ & 4850 & 8340 & 6540 & 7500 & - \\
\hline $\mathrm{pH}$ & 7.84 & 8.25 & 7.93 & 7.43 & $6.5-9$ \\
\hline Sludge volume / mL & - & 6.4 & 12.8 & 15 & - \\
\hline
\end{tabular}

PtCo-platinum cobalt units; NTU - nephelometric turbidity units; TDS-total dissolved solids 


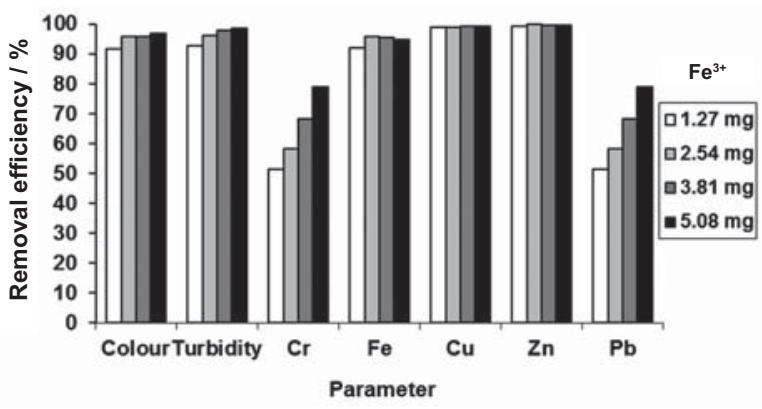

Figure $2 \mathrm{FeCl}_{3} \times 6 \mathrm{H}_{2} \mathrm{O}$ treatment removal efficiency. $\mathrm{Fe}^{3+}$ amount expressed per $50 \mathrm{~mL}$ of wastewater.

\section{Combined treatment with $\mathrm{CaO}$ and ferric chloride}

In combination with $5.08 \mathrm{mg}$ of $\mathrm{Fe}^{3+} \mathrm{CaO}$ lowered the concentrations of all heavy metals below the discharge limit as early as $0.25 \mathrm{~g}$ per $50 \mathrm{~mL}$ (Figure $3)$. Any further increase in the amount of $\mathrm{CaO}$ was

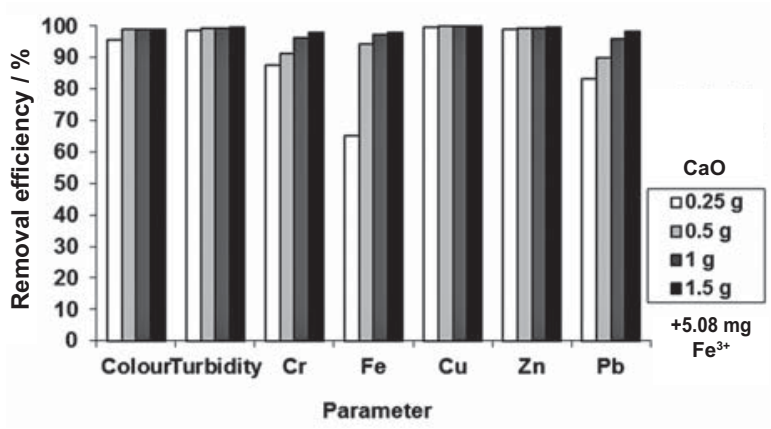

Figure 3 Combined treatment removal efficiency. $\mathrm{CaO}$ and $\mathrm{Fe}^{3+}$ added in the form of $\mathrm{FeCl} \times 6 \mathrm{H}_{2} \mathrm{O}$.

followed by a significant linear increase in the removal efficiency for $\mathrm{Fe}, \mathrm{Cr}$, and $\mathrm{Pb}$, while the removal efficiency for the other four parameters increased slightly. The final removal efficiencies with the highest doses of $\mathrm{CaO}(1.50 \mathrm{~g}$ per $50 \mathrm{~mL}$ ) were $99.41 \%$, $100.00 \%, 97.87 \%, 99.09 \%, 99.90 \%, 99.46 \%$, and $98.33 \%$ for colour, turbidity, $\mathrm{Cr}, \mathrm{Fe}, \mathrm{Cu}, \mathrm{Zn}$, and $\mathrm{Pb}$, respectively.

Figure 4 compares the best removal efficiencies of the three treatment methods. The analysis of variance showed a statistically significant difference $(\mathrm{P}<0.05)$ in mean removal efficiencies between the treatment methods for all parameters. Significant differences were confirmed by the Student-Newman-Keuls test. The most efficient method in removing all seven parameters was the combined treatment. For colour, $\mathrm{Cr}, \mathrm{Cu}, \mathrm{Zn}$, and $\mathrm{Pb}$, the removal efficiencies increased in the following order: $\mathrm{FC}<\mathrm{CaO}<\mathrm{CaO}+\mathrm{FC}$, while for turbidity and $\mathrm{Fe}$ this order was as follows: $\mathrm{CaO}<\mathrm{FC}<\mathrm{CaO}+\mathrm{FC}$. Better performance of $\mathrm{CaO}$ than

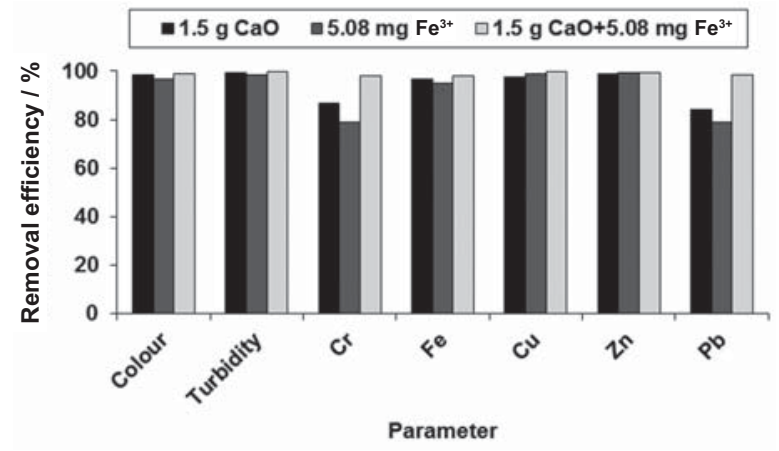

Figure 4 Comparison of the best removal efficiencies between the three treatment methods (treatment of $50 \mathrm{~mL}$ of wastewater with $1.50 \mathrm{~g} \mathrm{CaO}, 5.08 \mathrm{mg}$ $\mathrm{Fe}^{3+}$ in the form of $\mathrm{FeCl}_{3} \times 6 \mathrm{H}_{2} \mathrm{O}$ and their combination).

FC in the removal of $\mathrm{Cu}$ and $\mathrm{Pb}$ is probably related to the heat released by hydration of $\mathrm{CaO}$ that destroyed $\mathrm{Cu}$ and $\mathrm{Pb}$ organic complexes (10). Consequently, elements liberated from the organic ligands into the solution could be removed easily by hydroxide precipitation and coagulation/flocculation. The destruction of organic matter during the hydration of $\mathrm{CaO}$ could also explain better removal performance of colour by $\mathrm{CaO}$ compared to $\mathrm{FC}$ (12).

Taking into account the cost of $\mathrm{CaO}$ and $\mathrm{FC}$ and their consumption per $\mathrm{m}^{3}$ of treated water, the approximate cost of the combined treatment is $10.3 €$ per $\mathrm{m}^{3}$. From what we learn, this is at the lower half of the price range for this kind of wastewater treatment, but we have no data to support it.

With the combined treatment $\mathrm{Cr}, \mathrm{Fe}, \mathrm{Cu}, \mathrm{Zn}$, and $\mathrm{Pb}$ levels were 26, 56, 63, 33, and 38 times lower than the maximum allowed level set by the Croatian regulations (13), respectively.

Our earlier toxicological study (14) showed that the treated effluent with similar $\mathrm{Cr}, \mathrm{Fe}, \mathrm{Cu}, \mathrm{Zn}$, and $\mathrm{Pb}$ levels did not cause any significant toxic effect on HEp2 and HeLa human cell lines or on human white blood cells. Similarly, treated wastewater in our earlier studies produced no significant toxic effects on either bacterial cell lines (TA98 and TA100) or HEp2 and HeLa human cell lines (15) or on duckweed (16). Gajski et al. (17) found that the leachate of solidified sewage sludge containing $0.110 \mathrm{mg} \mathrm{L}^{-1}$ of $\mathrm{Cr}$, $0.240 \mathrm{mg} \mathrm{L}^{-1}$ of Fe, $0.066 \mathrm{mg} \mathrm{L}^{-1}$ of $\mathrm{Cu}, 0.080 \mathrm{mg} \mathrm{L}^{-1}$ of $\mathrm{Zn}$, and $0.060 \mathrm{mg} \mathrm{L}^{-1}$ of $\mathrm{Pb}$ did not cause significant toxic effects on human blood lymphocytes determined by the DNA diffusion assay, micronucleus test, and the comet assay. Medley and Clements (18) found no significant toxic effect of $\mathrm{Zn}$ concentrations lower than $0.200 \mathrm{mg} \mathrm{L}^{-1}$ on diatom communities. Zinc at values 
similar to ours also did not have a toxic effect on a benthic macroinvertebrate community studied by Clements and Kiffney (19).

In addition, our concentrations in the treated wastewater are significantly lower than the $\mathrm{LC}_{50}$ values for $\mathrm{Cu}, \mathrm{Zn}, \mathrm{Pb}$, and $\mathrm{Cr}$ obtained by Calabrese et al. (20). All this suggests that a discharge of effluents treated by a combination of $\mathrm{CaO}$ and $\mathrm{FC}$ in the final concentrations described in our study will not have a toxic effect on local marine life.

\section{Sludge treatment}

The sludge formed during the purification must be dewatered by filtration on filter presses, stored in a pool, and handed over to the authorised waste collection service for further disposal.

\section{CONCLUSION}

Combined treatment yielded the best performance in the removal of organic (colour, turbidity) constituents and heavy metals from boat pressure washing wastewater. However, $\mathrm{CaO}$ treatment alone yielded the highest TDS increase and generated the lowest volume of sludge. The remaining concentrations of heavy metals in the effluent following the combined treatment are lower than or comparable with previously published data (14-17), and we do not expect any toxic effects on the environment and humans. All in all, the combined treatment of marine wastewater with $\mathrm{CaO}$ and $\mathrm{FC}$ has turned out to be efficient, cost-effective, and user-friendly.

\section{REFERENCES}

1. Oreščanin V, Nad K, Kukec L, Gajski A, Sudac D, Valković V. Trace element analysis of water and sediment before/after passing a waste water treatment plant. J Trace Microprobe Tech 2002;21:325-34.

2. Walker GM, Hanna J-A, Allen SJ. Treatment of hazardous shipyard wastewater using dolomitic sorbents. Water Res 2005;39:2422-8

3. Ottosen LM, Arevalo E, Stichnothe H, Calmano W. Ferric flocks to remove $\mathrm{Zn}$ and $\mathrm{Cu}$ from dockyard wastewater. Environ Chem Lett 2006;3:164-8.

4. Oreščanin V, Nad K, Valković V, Mikulić N, Meštrović O. Red mud and waste base: raw materials for coagulant production. J Trace Microprobe Tech 2001;19:419-28.

5. Oreščanin V, Tibljas D, Valković V. A study of coagulant production from red mud and its use heavy metals removal. J Trace Microprobe Tech 2002;20:233-45.
6. Prasad R, Schafran GC. Characterization of tributyltin in shipyard waters and removal through laboratory and fullscale treatment. Water Res 2006;40:453-62.

7. Arevalo E, Calmano W. Studies on electrochemical treatment of wastewater contaminated with organotin compounds. J Hazard Mater 2007;146:540-5.

8. Vreysen S, Maes A, Wullaert H. Removal of organotin compounds, $\mathrm{Cu}$ and $\mathrm{Zn}$ from shipyard wastewaters by adsorption - flocculation: A technical and economic analysis. Mar Pollut Bull 2008;56:106-15.

9. Oreščanin V, Kollar R, Nad K. The application of the ozonation/electrocoagulation process for the treatment of wastewater from boat pressure washing. J Environ Sci Health A Tox Hazard Subst Environ Eng 2011;46,1338-45.

10. Oreščanin V, Mikulić N, Lovrenčić Mikelic I, Posedi M, Kampić S, Medunić g. The bulk composition and leaching properties of electroplating sludge prior/following the solidification/stabilization by calcium oxide. J Environ Sci Health A Tox Hazard Subst Environ Eng 2009;44:1282-8.

11. Oreščanin V, Lovrenčić I, Mikelić L, Lulić S. Applicability of MiniPal 4 compact EDXRF spectrometer for soil and sediment analysis. X-Ray Spectrometry 2008;37:508-11.

12. Oreščanin V, Ruk D, Kollar R, Lovrenčić Mikelić I, Nad K, Mikulić N. A combined treatment of landfill leachate using calcium oxide, ferric chloride and clinoptilolite. J Environ Sci Health A Tox Hazard Subst Environ Eng 2011;46:3238.

13. Pravilnik o graničnim vrijednostima emisija otpadnih voda [Regulations on limit values of the emission of wastewaters, in Croatian]. Narodne novine 87/2010.

14. Oreščanin V, Kopjar N, Durgo K, Elez L, Findri-Guštek, S, Franekić Colić J. Citotoxicity status of electroplating wastewater prior/after neutralization/purification with alkaline solid residue of electric arc furnace dust. J Environ Sci Health A Tox Hazard Subst Environ Eng 2009;44:2738.

15. Durgo K, Horvat T, Oreščanin V, Mikelić L, Franekić Colić J, Lulić S. Cytotoxicity and mutagenicity study of waste and purified water samples from electroplating industries prepared by use of ferrous sulfate and wood fly ash. J Environ Sci Health A Tox Hazard Subst Environ Eng 2005;40:94957.

16. Horvat T, Vidaković-Cifrek Z, Oreščanin V, Tkalec M, Pevalek-Kozlina B. Toxicity assessment of heavy metal mixtures by Lemna minor L. Sci Total Environ 2007;384:22938.

17. Gajski G, Oreščanin V, Garaj-Vrhovac V. Cytogenotoxicity of sewage sludge leachate before and after calcium oxide based solidification in human lymphocytes. Ecotoxicol Environ Saf 2011;74:1408-15.

18. Medley CN, Clements WH. Responses of diatom communities to heavy metals in streams: the influence of longitudinal variation. Ecol Appl 1998;8:631-44.

19. Clements WH, Kiffney PM. The influence of elevation on benthic community responses to heavy metals in Rocky Mountain streams. Can J Fish Aquat Sci 1995;52:1966-77.

20. Calabrese A, Collier RS, Nelson DA, MacInnes JR. The toxicity of heavy metals to embryos of the American oyster Crassostrea virginica. Mar Biol 1973;18:162-6. 


\section{Sažetak}

\section{OBRADA OTPADNIH VODA OD PRANJA BRODOVA KOMBINACIJOM FIZIČKO-KEMIJSKIH METODA}

Radi smanjenja toksičnosti otpadnih voda koje nastaju pranjem brodova premazanih bojama protiv obraštaja primijenjene su tri metode obrade: (1) kemijsko taloženje s pomoću kalcijeva oksida, koagulacija/flokulacija s pomoću željezova klorida (FC) i (3) kombinacija ovih dviju metoda. Sve tri metode dale su zadovoljavajuće rezultate u uklanjanju boje, mutnoće, kroma, željeza, bakra, cinka i olova. Koncentracije teških metala niže od graničnih vrijednosti postignute su nakon tretmana s $1 \mathrm{~g} \mathrm{CaO}$ ili 2,54 mg Fe ${ }^{3+}$ dodanog u obliku $\mathrm{FeCl}_{3} \times 6 \mathrm{H}_{2} \mathrm{O}$ ili kombinacijom od $0,25 \mathrm{~g} \mathrm{CaO}$ i $5,08 \mathrm{mg} \mathrm{Fe}^{3+}$ na $50 \mathrm{~mL}$ otpadne vode. Optimalne vrijednosti uklanjanja boje, mutnoće, $\mathrm{Cr}, \mathrm{Fe}, \mathrm{Cu}, \mathrm{Zn}$ odnosno $\mathrm{Pb}$ s pomoću $\mathrm{CaO}$ (1,50 g na $50 \mathrm{~mL}$ ) bile su 99,07\%, $99,54 \%, 86,97 \%, 96,77 \%, 97,81 \%, 98,76 \%$ odnosno $84,10 \%$, dok su u slučaju željezova klorida te vrijednosti iznosile 98,76 \%, 99,85\%, 78,99\%, 97,35\%, 96,77\%, 98,53\% odnosno 78,99\%. Značajno viši stupanj uklanjanja postignut je kombinacijom navedenih dvaju pristupa čime je postignuta maksimalna učinkovitost uklanjanja i to 99,41 \% boje, 100,00 \% mutnoće, 97,87 \% kroma, 99,09 \% željeza, 99,90 \% bakra, 99,46 \% cinka i 98,33 \% olova. Za boju, krom, bakar, cink i olovo učinkovitost uklanjanja raste ovim redoslijedom: $\mathrm{FC}<\mathrm{CaO}<\mathrm{CaO}+\mathrm{FC}$ dok za mutnoću i željezo raste u ovom nizu: $\mathrm{CaO}<\mathrm{FC}<\mathrm{CaO}$ + FC. Sukladno očekivanju, sve tri metode povećavaju koncentraciju ukupne otopljene tvari u konačnom ispustu.

Naši rezultati pokazuju da je primijenjeni način pročišćavanja otpadnih voda iz marina kombinacijom kalcijeva oksida i željezova klorida učinkovit s obzirom na stupanj uklanjanja, s povoljnim odnosom stupnja pročišćavanja i cijene te jednostavan za primjenu.

KLJUČNE RIJEČI: boja, boje protiv obraštaja, CaO, mutnoća, teški metali, željezo(III) klorid

\section{CORRESPONDING AUTHOR:}

Višnja Oreščanin

Advanced Energy Ltd.

V. Prekrata 43, Zagreb, Croatia

E-mail:vorescan@gmail.com 